\title{
Painful oculomotor nerve palsy due to lymphocytic hypophysitis
}

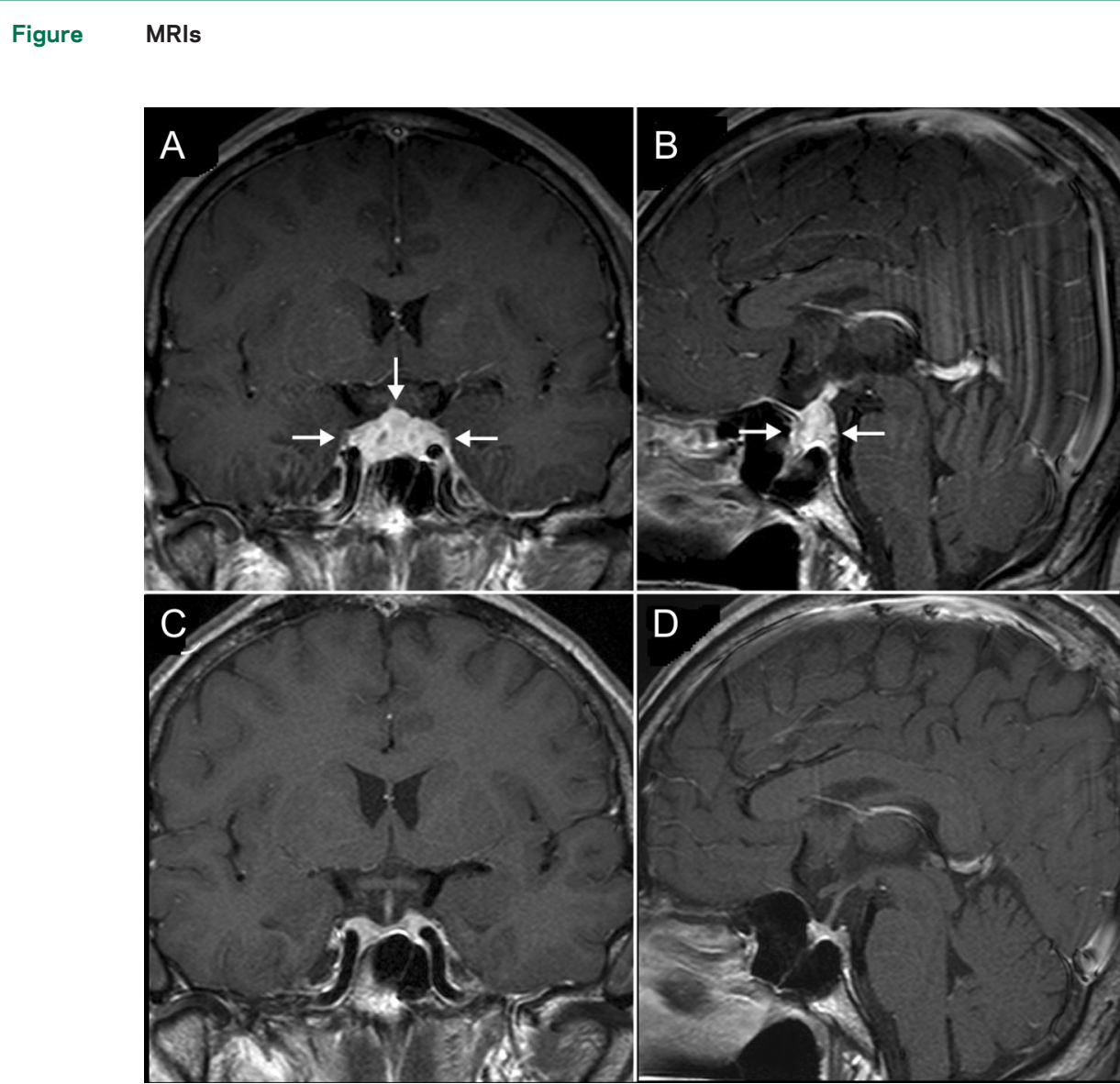

Gadolinium-enhanced coronal (A) and sagittal (B) sellar MRIs reveal enlarged pituitary gland and thickened pituitary stalk with a strong enhancement, which were normalized on follow-up MRIs (C and D) 1 month later.

A 40-year-old man developed headache and a left oculomotor nerve palsy. MRI revealed diffuse enlargement of the pituitary gland and thickening of the pituitary stalk with strong gadolinium enhancement (figure). CSF examination showed a lymphocytic pleocytosis; there were laboratory findings of panhypopituitarism, but no related symptoms. We administered IV methylprednisolone. The headache and ophthalmoplegia showed a dramatic response, resolving 5 days later. Lymphocytic hypophysitis is characterized by autoimmune inflammation of the pituitary gland, ${ }^{1}$ usually presenting with headache and visual disturbances in women, rarely with oculomotor nerve palsy. ${ }^{1,2}$ Glucocorticoids effectively reduce inflammation and support adrenal function.

\section{Jangsup Moon, MD, Ji Soo Kim, MD, PhD, Seoul, Republic of Korea}

Study funding: Supported by a grant of the Korea Health 21 R\&D Project, Ministry of Health \& Welfare, Republic of Korea (A080750). Disclosure: Dr. Moon reports no disclosures. Dr. Kim serves as an Associate Editor of Frontiers in Neuro-otology and on the editorial boards of the Journal of Korean Society of Clinical Neurophysiology, the Journal of Clinical Neurology, Frontiers in Neuro-ophthalmology, and Journal of Neuro-ophthalmology and receives research support from SK Chemicals, Co. Ltd.

Address correspondence and reprint requests to Dr. Ji Soo Kim, Department of Neurology, College of Medicine, Seoul National University, Seoul National University Bundang Hospital, 300 Gumi-dong, Bundang-gu, Seongnam-si, Gyeonggi-do, 463-707, Korea; jisookim@snu.ac.kr

1. Rivera JA. Lymphocytic hypophysitis: disease spectrum and approach to diagnosis and therapy. Pituitary 2006;9:35-45.

2. Caturegli P, Newschaffer C, Olivi A, et al. Autoimmune hypophysitis. Endocr Rev 2005;26:599-614. 


\section{Neurology}

\section{Painful oculomotor nerve palsy due to lymphocytic hypophysitis Jangsup Moon and Ji Soo Kim}

Neurology 2011;76;104

DOI 10.1212/WNL.0b013e318203e99e

This information is current as of December 27, 2010

\section{Updated Information \& Services}

\section{References}

\section{Subspecialty Collections}

\section{Permissions \& Licensing}

\section{Reprints}

including high resolution figures, can be found at: http://n.neurology.org/content/76/1/104.full

This article cites 2 articles, 0 of which you can access for free at: http://n.neurology.org/content/76/1/104.full\#ref-list-1

This article, along with others on similar topics, appears in the following collection(s):

All Neuro-ophthalmology

http://n.neurology.org/cgi/collection/all_neuroophthalmology Diplopia (double vision)

http://n.neurology.org/cgi/collection/diplopia_double_vision Endocrine

http://n.neurology.org/cgi/collection/endocrine

Neuroendocrinology

http://n.neurology.org/cgi/collection/neuroendocrinology

Ocular motility

http://n.neurology.org/cgi/collection/ocular_motility

Information about reproducing this article in parts (figures,tables) or in its entirety can be found online at:

http://www.neurology.org/about/about_the_journal\#permissions

Information about ordering reprints can be found online: http://n.neurology.org/subscribers/advertise

Neurology ${ }^{\circledR}$ is the official journal of the American Academy of Neurology. Published continuously since 1951, it is now a weekly with 48 issues per year. Copyright Copyright @ 2010 by AAN Enterprises, Inc.. All rights reserved. Print ISSN: 0028-3878. Online ISSN: 1526-632X.

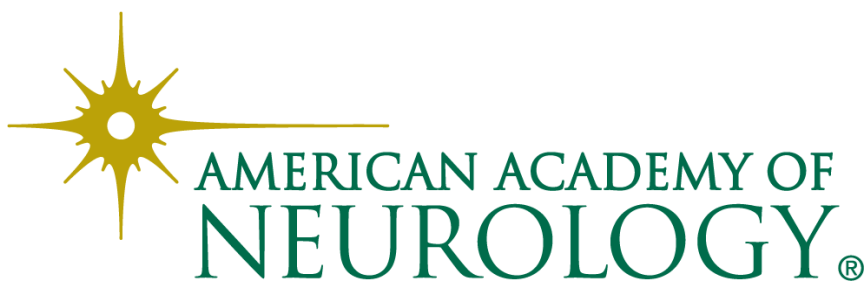

